\title{
INDONESIA AND THE TRANS-PACIFIC PARTNERSHIP AGREEMENT (TPPA): THE LUXURY OF TIME
}

\author{
David Price*
}

* Charles Darwin University, Australia

\section{Article Info}

Received : 13 June 2016 | Received in revised form : 18 February 2017| Accepted : 23 March 2017

Corresponding author's e-mail : david.price@cdu.edu.au

\begin{abstract}
This Presentation examines Indonesia's recent declaration to join the Trans-Pacific Partnership (TPPA), as announced by President Widodo during a State visit to the United States in October 2015, and his subsequent announcement that this accession would occur within two years. The Presentation explores both the implications for Indonesia of TPPA membership as well as the likelihood of achieving the President's twoyear aspiration. It focuses on one of the more controversial elements of the TPPA, namely, the inclusion of Investor-state dispute settlement (ISDS) provisions, particularly in light of former President Yudhoyono's 2014 determination to terminate all its bilateral investment treaties with ISDS provisions. In joining the TPPA, Indonesia commits to its ISDS provisions, likely without carve-outs or reservations. The change may perhaps be driven by a perceived imperative to open up Indonesian economy to greater international investment, and to compete with other growing ASEAN economies. However, the future of the TPPA is not necessarily assured, with the U.S. Presidential election and U.S. domestic politics. President Obama considers it a key element of his Presidential legacy, and has Congressional agreement for a "fast-track" vote, but both Presidential candidates, as well as members of both parties in Congress, have at times soundly criticised or even rejected the TPPA. It appears increasingly unlikely that he will succeed in achieving ratification as he enters his Presidency's "lame duck" period. The Presentation also examines the implications for Indonesia and for the TPPA if the United States unduly delays or even rejects its own domestic ratification of the TPPA.
\end{abstract}

Keywords: Trans-Pacific Partnership Agreement, TPPA, Indonesia, Trade, United States

\section{Abstrak}

Tulisan ini akan meninjau pernyataan Presiden Widodo yang menyatakan bahwa Indonesia akan mengikuti Trans-Pacific Partnership Agreement (TPPA) saat kunjungan kenegaraan ke Amerika Serikat di bulan Oktober 2015, serta pernyataan lanjutan yang menyatakan bahwa aksesi TPPA akan diharapkan selesai dalam waktu dua tahun. Tulisan ini mengeksplorasi baik dampak Indonesia menjadi peserta TPPA dan juga kemungkinan jangka waktu aksesi Indonesia dalam waktu dua tahun sebagaimana yang diharapkan oleh Presiden. Tulisan ini berfokus pada unsur kontroversial dari TPPA, yaitu adalah pencantuman ketentuan penyelesaian sengketa investor dengan Negara (ISDS). Hal ini khususnya dalam kaitan dengan kebijakan Presiden Yudhoyono pada tahun 2014 yang akan mengakhiri perjanjian investasi bilateral yang memuat ketentuan ISDS. Dalam menjadi anggota TPPA, Indonesia akan mengikatkan diri pada ketentuan ISDS yang ada, dengan kemung kinan tanpa pengecualian atau pensyaratan. Perubahan tersebut kemungkinan didorong oleh pembukaan ekonomi Indonesia terhadap investasi internasional, dan untuk bersaing dengan ekonomi negara ASEAN lainnya yang tumbuh. Akan tetapi, masa depan TPPA tidak dapat dijamin dengan pengaruh pemilihan Presiden Amerika Serikat dan politik domestik dari AS. Presiden Obama menganggap bahwa TPPA adalah bagian penting dari warisan masa kepresidenannya, dan telah membuat persetujuan dengan Kongres untuk membuat pemungutan suara jalur cepat ("fast-track" vote), akan tetapi, kedua kandidat Presiden yang dan kedua partai di Kongres mengiritisi TPPA bahkan menolak TPPA secara tegas. Kemungkinan, Presiden Obama tidak akan berhasil untuk mencapai ratifikasi TPPA mengingat telah memasuki masa akhir kepresidenannya. Tulisan ini juga meninjau implikasi TPPA terhadap Indonesia jika AS menunda atau bahkan menolak ratifikasi dari TPPA.

Kata kunci: Trans-Pacific Partnership Agreement, TPPA, Indonesia, Perdagangan, Amerika Serikat 


\section{INTRODUCTION}

The Trans-Pacific Partnership Agreement (TPPA) is a multilateral free trade agreement involving 12 Pacific Rim countries, namely, Australia, Brunei Darussalam, Canada, Chile, Japan, Malaysia, Mexico, New Zealand, Peru, Singapore, the United States and Vietnam. Negotiations commenced in 2008 and were completed on October 5, 2015. The Agreement was signed by the negotiating parties on February 4, 2016 in Auckland, New Zealand.

According to its promoters, the TPPA aims to further liberalise the economies of the Asia-Pacific region. Accordingly, it encompasses the broad spectrum of trade and investment areas, including trade in goods, rules of origin, trade remedies, sanitary and phytosanitary measures, technical barriers to trade, trade in services, intellectual property, government procurement and competition policy. Its declared goals are to strengthen and broaden the mutually-beneficial linkages between member economies; enhance regional and global competitiveness; support the creation of jobs and new economic opportunities; promote economic growth and development; support innovation and help to alleviate poverty; and ensure the greatest benefits for the member peoples. ${ }^{1}$ The Agreement constitutes a voluminous and complex treaty, comprising 30 chapters, 2700 pages (6000 pages including Schedules and side letters).

The TPPA developed out of an original trade agreement between Brunei, Chile, New Zealand and Singapore, which entered into force on May 28, 2006. ${ }^{2}$ The objective of this original agreement was to eliminate 90 percent of all tariffs between member countries by January 2006, and reduce all trade tariffs to zero by 2015. During 2008 the United States and separately Australia, Malaysia, Peru, and Vietnam entered negotiations on an agreement expanded in scope and membership with the original four members, thus dramatically changing both the dimension and the dynamics between the new negotiating partners. During the November 2010 APEC summit the then nine negotiating countries set a target for settlement of negotiations by the subsequent APEC summit in November 2011. However, it has taken another four years of intense and at times contentious negotiation and deal-making to reach sufficient consensus to enable an agreement to be settled in October 2015 and signed in February 2016.

The expression of that consensus amongst the negotiating parties on the TPPA and what it represents was heralded in the Ministerial Statement following the signing of the Agreement:

"TPP will set a new standard for trade and investment in one of the world's fastest growing and most dynamic regions. We signatories comprise nearly 40 percent of global GDP, a market of more than 800 million people, and around one third of world trade. Our goal is to enhance shared prosperity, create jobs and promote sustainable economic development for all of our nations."3

The signatories' objective is to expand the Agreement and to bring other countries into the fold. At their first meeting since the Signing, held in Peru in May 2016, the

1 See Australian Government Department of Foreign Affairs and Trade, "Trans-Pacific Partnership Agreement: Latest News," May 17, 2016, at http://dfat.gov.au/trade/agreements/tpp/pages/transpacific-partnership-agreement-tpp.aspx

2 See, Australian Government Department of Foreign Affairs and Trade, "Trans-Pacific Partnership Leaders Statement," http://www.dfat.gov.au/trade/tpp/TPP Leaders Statement.pdf, accessed 12 November 2011,

3 Australian Government Department of Foreign Affairs and Trade, "Trans-Pacific Partnership Ministers' Statement," http://dfat.gov.au/trade/agreements/tpp/news/Pages/trans-pacific-partnershipministers-statement.aspx, accessed 4 February 2015. 
signatories noted that a number of economies in the region have expressed an interest in joining the TPP. These economies reportedly include Indonesia, the Philippines, Colombia, South Korea, Sri Lanka, Taiwan and Thailand. China has maintained close interest, but not an interest in joining, promoting an agreement in competition to the United States with the Regional Comprehensive Economic Partnership (RCEP).

The signatories agreed to continue to work bilaterally with interested economies to ensure that these interested economies understand the standards and rules set forth in the TPPA and the requirements that they need to meet if they wish to join after the Agreement enters into force. ${ }^{4}$

\section{THE CURRENT STATUS OF THE TPPA}

As stated by the negotiating parties on the successful conclusion of the Agreement in October 2015, the signing of the Agreement would:

"signal[s] an important milestone and the beginning of the next phase for the TPPA. Our focus now turns to the completion of our respective domestic processes." ${ }^{\prime 5}$

While those domestic processes may be well established within the respective signatories, the processes of negotiating them may be both protracted and painful, with the eventual outcome not guaranteed or even certain in each case.

Article 30.5 of the TPPA allows for a number of options in respect of the timing of the Agreement coming into force. One the one hand, Clause 1 provides, rather optimistically, for the Agreement to come into force 60 days after all signatories notify their completion of the necessary domestic legal procedures for ratification.

Clause 2, however, makes allowance for both a realistic time frame and the likelihood of a number of signatories rejecting the Agreement. It provides for a two year time frame for at least a majority of the signatories to complete the necessary domestic legal procedures. The Clause stipulates that:

"2. In the event that not all original signatories have notified the Depositary in writing of the completion of their applicable legal procedures within a period of two years of the date of signature of this Agreement, it shall enter into force 60 days after the expiry of this period if at least six of the original signatories, which together account for at least 85 per cent of the combined gross domestic product of the original signatories in 2013 have notified the Depositary in writing of the completion of their applicable legal procedures within this period."

The fact that the Agreement requires ratification by original signatories who together account for 85 percent of combined gross domestic product (GDP) as at 2013 before it can come into force could be a major stumbling block for the Agreement's future status and even existence. The United States alone accounts for some 61 percent of the combined GDP of the original signatories, while Japan accounts for around 18 percent. The other 10 signatories together account for the remaining 21 percent; Canada's gross domestic product is the next largest at 6.7 percent - nevertheless representing a significant negative margin from Japan's statistic. This means that

${ }^{4}$ Australian Government Department of Foreign Affairs and Trade, "Joint Statement from Trans-Pacific Partnership Ministers' Meeting in Arequipa, Peru," http://dfat.gov.au/trade/agreements/tpp/news/ Pages/news.aspx, accessed 23 May 2016.

${ }^{5}$ Ibid.

6 Australian Government Department of Foreign Affairs and Trade, "TPP text and associated documents," $\quad$ http://dfat.gov.au/trade/agreements/tpp/official-documents/Pages/official-documents. aspx, accessed 6 October 2015. 
both the United States and Japan must be amongst the ratifying signatories for the Agreement to come into force. If either of these two signatories resile from or equivocate ratifying the Agreement, it cannot come into force.

The above stipulation of a two year time frame need not be an obstacle of gamechanging proportions, since Article 30.5(3) provides that in the event that the Agreement does not enter into force under clause 1 or 2 , it can still enter into force 60 days after the date on which at least six of the original signatories notify in writing of the completion of their applicable legal procedures. Nevertheless, the requirement of 85 percent of combined GDP of the original signatories is still mandated.

On the other hand, if both the United States and Japan, together accounting for just under 80 percent of combined GDP, ratify the Agreement, it will no doubt inevitably come into force. The balance of four more ratifications and five percent of combined GDP would soon be achieved (if it had not already been so) from amongst the remaining signatories. It would be most improbable that the remaining required signatories would in a bloc fail to ratify in order to prevent that outcome.

An incentive for ratification within the two year period is laid down in Article 30.5.4, which provides that if an original signatory does not ratify the Agreement before it comes into force:

"the [TPPA] Commission shall determine within 30 days of the date of the notification by that original signatory whether this Agreement shall enter into force with respect to the notifying original signatory."

Since key roles and functions of the Commission include, inter alia,

- reviewing the economic relationship and partnership among the Parties ${ }^{8}$;

- considering any proposal to amend or modify the Agreement ${ }^{9}$;

- determining whether the Agreement may enter into force for an original signatory notifying pursuant to Article $30.5 .4^{10}$;

- $\quad$ issuing interpretations of the provisions of the Agreement ${ }^{11}$;

it has the means and capacity to thus effectively at least influence or even determine the conditions of membership of later aspirants. This would seem to convey a warning to a tardy original signatory that concessions hard-won during the lengthy negotiation rounds ${ }^{12}$ as detailed in the Agreement's country-specific Annexes, Schedules and sideletters may well be subject to reduction or removal or even (in principle at least) the threat of a right of veto.

The crucial questions that arise, then, are what might be the likelihood of the Agreement not being ratified by either the United States or Japan, or both, and in the event of that being the case will the Agreement come into force? This raises a further question for Indonesia, namely, what strategy should it adopt in respect of its own aspirations for membership of the TPPA.

\footnotetext{
7 The TPPA Article 1.3 defines the Commission Trans-Pacific Partnership Commission established under Article 27.1 (Establishment of the Trans-Pacific Partnership Commission).

8 Trans-Pacific Agreement, Auckland, 4 February 2016, Article 27.2.1(a).

${ }^{9}$ Ibid., Article 27.2.1(c).

10 Ibid., Article 27.2.1(h).

11 Ibid., Article 27.2.2(f).

12 Ibid., Article 30.5.4.
} 


\section{AN UNCERTAIN FUTURE FOR THE TPPA?}

\section{A. The Japanese Ratification Environment}

In the case of Japan, the TPPA needs to go before the Cabinet Legislation Bureau and then the Cabinet. The Cabinet can conclude the Agreement treaty, but it must obtain prior or subsequent approval by a majority of the Japanese Parliament, the Diet. The implementing Bill may be first referred to a committee for consideration. ${ }^{13}$

The Japanese Government reportedly finalised a bill seeking ratification of the TPPA as well as 11 pieces of related legislation in early 2016, with an initial intention of ratifying the Agreement and the related legislation by the end of the then Diet session (which ended in June). ${ }^{14}$ However, the Government and ruling parties have apparently decided to defer consideration of the Agreement, the enabling legislation and the related bills until after the current ordinary Diet session, according to party sources, because of more pressing domestic issues and perceptions concerning the level of objection from the opposition parties. ${ }^{15}$

The Government intends to convene an extraordinary session of the Diet at some time during the forthcoming Japanese autumn, for intense examination of the TPPA, and possible approval and enactment of the necessary domestic legislation. ${ }^{16}$ The deferral would seem to constitute the Government's cautious approach to ratification in the face of opposition to the Agreement from non-government organisations, the agriculture/farm sector interest groups, and conservative elements within the opposition parties. Government and opposition parties do not appear to perceive a need to rush to deliberate the Agreement.

However, even with this cautious approach, it seems that Japan will ratify the Agreement, and be amongst the early signatories to do so.

\section{B. The United States Ratification Environment}

In the case of the United States, the passage of the TPPA to ratification is subject to legal procedures as laid down in the Trade Promotion Authority (TPA) granted to the President by Congress in June 2015. The TPA is a legislative procedure enacted by Congress, through which Congress defines U.S. negotiating objectives and priorities for trade agreements. ${ }^{17}$ It spells out a detailed oversight and consultation process during trade negotiations, to which the President is required to adhere. Under TPA, Congress retains the authority to review and decide whether any proposed U.S. trade agreement will be implemented. At the end of the negotiation and consultation process, Congress gives the Agreement an "up or down" vote, without amendment.

The TPA provides for an expedited or "fast-track" Congressional ratification and implementation process through both the Senate and the House of Representatives. Congress may only vote "up or down" on a treaty, that is to accept or reject a treaty in its entirety. Congress is not able to accept in parts and reject the remainder, or to make amendments to a treaty. As part of the "fast-track" process, the TPA stipulates time

13 See Freshfields Bruckhaus Deringer, “Trans-Pacific Partnership," http://www.freshfields.com/ Current status tpp/

14 Ibid..

15 See The Mainichi, “Gov't abandons plans for TPP ratification during current Diet session,” http:// mainichi.jp/english/articles/20160420/p2a/00m/0na/011000c, accessed 20 April 2016.

${ }^{16}$ Ibid.

17 As enacted by the Trade Preferences Extension Act of 2015. See Office of the United States Trade Representative, "Trade Promotion Authority," https://ustr.gov/trade-agreements/other-initiatives/TradePromotion-Authority 
frames in respect of the various stages of the process applicable to both President and Congress. On 12 August 2017 the president formally advised Congress that he would be transmitting a bill to implement the TPPA, an action required under the TPA.

Considerable uncertainty and speculation abounds concerning the United States' future position on the TPPA, with opposition coming both from Republicans and Democrats in both chambers of Congress and from the two Presidential candidates. The widespread opposition to the Agreement within the American electorate across the broad spectrum of political persuasion has also made its presence very public at both the Presidential Conventions. Opponents variously argue that the TPPA will harm consumers by flooding the domestic market with cheap foreign goods, will cost millions of American jobs and will impose restrictions on workers' rights. It will harm the environment, remove safeguards for American investors, and compromise American security. They also argue that the Agreement gives too much power and benefit to Wall Street and multinational corporations at the expense of the American working and middle classes.

Both Presidential candidates have been critical about the TPPA. Republican Candidate Donald Trump has been consistently scathing and condemnatory, describing it throughout his campaign as a "horrible deal," and a deal that was "designed for China to come in, as they always do, through the back door and totally take advantage of everyone," apparently oblivious to the view that China has never been party to any of the negotiations. ${ }^{18}$ More recently he has described it as "a continuing rape of our country," and promised to withdraw the United States from the TPPA if Congress ratified it. ${ }^{19}$

Democratic Candidate Hillary Clinton, previously supportive of the Agreement while Secretary of State, showed a change in her position as she sought the Democratic Party's Presidential nomination. As secretary of State, she was supporting the TPPA as the "new gold standard" in regional trade agreements. By October 2015, she declared during her campaign for the Democratic nomination that:

"As of today, I am not in favor of what I have learned about it ... I don't believe it's going to meet the high bar I have set."20

More recently, in August 2016, and as the confirmed Democrat candidate, Clinton declared during a campaign address that:

"I will stop any trade deal that kills jobs or holds down wages, including the Trans-

Pacific Partnership ....I oppose it now, I'll oppose it after the election and I'll oppose it as president." 21

In Congress, opposition has been strong in both chambers on both sides, to the point of virulent, amongst both Republican and Democrat members. Senate Majority Leader Mitch McConnell has declared that:

"It certainly shouldn't come before the election ... and I have some serious problems with what I think it is ... But I think the president would be making a big mistake to

18 Donald Trump, “Republican presidential debate, Milwaukee," https://www.youtube.com/ watch?v=kihtDxtcZ54, accessed 10 November 2015.

${ }^{19}$ Cristiano Lima, "Trump calls trade deal 'a rape of our country," Politico, at http://www.politico.com/ story/2016/06/donald-trump-trans-pacific-partnership-224916\#ixzz4IotfOffD, accessed August 28, 2016.

${ }^{20}$ PBS Newshour, "Hillary Clinton says she does not support Trans-Pacific Partnership," http://www. pbs.org/newshour/rundown/hillary-clinton-says-she-does-not-support-trans-pacific-partnership/, 7 October 2015.

21 Adam Behsudi, “Obama puts Congress on notice: TPP is coming," Politico, http://www.bilaterals. org/?obama-puts-congress-on-notice-tpp, accessed 12 August 2016. 
try to have that voted on during the election. There's significant pushback all over the place." 22

Chairman of the Senate Finance Committee, Orrin Hatch, has also expressed strong concerns about the substance of the deal, in particular the exclusivity period for intellectual property protection of patents covering biologic drugs and stated that he will push the current administration to renegotiate these provisions. ${ }^{23}$

In the House of Representatives, Speaker of the House, Paul Ryan, has accused the President of messing up the negotiations, and stated that the Agreement has problems, "and there can be no movement before these concerns are addressed."

Opening up the TPPA to re-negotiation of certain parts that are subject to particular domestic resistance, as Hillary Clinton hints when she opposes it in its present form, could challenge the existence of the Agreement if attempted before it has come into force; it would be a different challenge but quite feasible if done after it comes into force. Pursuant to Article 30.2 of the Agreement, amendment is permissible, but once the Agreement has come into force. Article 30.2 provides that the "Parties may agree, in writing, to amend this Agreement. When so agreed by all Parties and approved in accordance with the applicable legal procedures of each Party ...". Even though it is not unheard of, and provision exists, for particular points to be revised after conclusion of an agreement, doing so is far from easy, and could unravel the delicate balance of concessions achieved in negotiations.

However, to attempt to open up the Agreement beforehand in order to obtain modification to suit certain groups within the United States environment raises the very real likelihood of other signatories seeking to do likewise on issues of concern to their negotiators or their own domestic electorates in opposition. Such actions would at best further delay and even compromise individual ratification by other signatories; at worst it could militate against the Agreement ever coming into force. The President has reportedly asserted that renegotiating any aspects of the TPPA will almost certainly cause the demise of the Agreement. ${ }^{25}$

President Obama and leaders of other TPPA countries suggest that re-opening negotiations to try to alter the terms would likely mean the death-knell of the whole Agreement, in light of the difficulties and challenges experienced in reaching a successful conclusion. Any amendments, changes or variations demanded by its American critics would have to be restricted side deals or less formal arrangements that would not have the same force as a ratified act of Congress.

President Obama, on the other hand, considers the TPPA as a lynch-pin of the United States' "Asia-pivot" strategy, a crucial foreign policy strategy that he has consistently promoted throughout his presidency. He also views it as a key element of his presidential legacy. On the occasion of the successful conclusion of negotiations, the President described the TPPA as:

"an agreement that reflects America's values and gives our workers the fair shot at success they deserve...

22 Paul Cane and David Nakamura, "McConnell warns that trade deal can't pass Congress before 2016 elections," Washington Post, December 14, 2015, at https://www.washingtonpost.com/politics/mcconnellwarns-that-trade-deal-cant-pass-congress-before-2016-elections/, accessed 12 August 2016.

${ }^{23}$ Vicki Needham, "Finance chair: Trade deal may need to be renegotiated," The Hill, November 6, 2015, at http://thehill.com/policy/finance/259426-hatch-concerned-tpp-may-fall-short-of-congressionalexpectations

${ }^{24}$ Behsudi, "Obama puts Congress on notice"

${ }^{25}$ J. Lederman, "Brushing off Clinton's critique, Obama presses ahead on TPP," Associated Press, Washington, as reported in the Jakarta Post, at http://www.thejakartapost.com/news/2016/08/03/ brushing-off-clintons-critique-obama-presses-ahead-on-tpp.html, accessed 15 August 2016. 
When more than 95 percent of our potential customers live outside our borders, we can't let countries like China write the rules of the global economy. We should write those rules, opening new markets to American products while setting high standards for protecting workers and preserving our environment .... It's an agreement that puts American workers first ... we can help our businesses sell more Made in America goods and services around the world, and we can help more American workers compete and win"26

Accordingly, he is pushing hard to have the TPPA approved and ratified whilst he is still in office. But it appears increasingly unlikely that he will succeed in doing so, either during the current presidential campaign period until early November 2016 or later as he enters the "lame duck" period of his presidency, that is, the period between the election and the inauguration of the new President on January 20, 2017. More recently he appears to have recognised the futility of a successful outcome before the presidential elections and instead is focusing on passage through Congress during its "lame-duck" session. In early August during the State visit of Singapore Prime Minister Lee Hsien Loong to the United States, the President confirmed that he has given up attempting to get the TPPA through Congress during the campaign season but is still pursuing a vote during the "lame-duck" period:

"Hopefully, after the election is over and the dust settled, there will be more attention to the actual facts behind the deal and it won't just be a political symbol or a political football. ${ }^{27}$

While there may be reason to view the declared positions and accompanying rhetoric on the TPPA by both presidential candidates as largely electioneering puff and posture deferring to influential powerbrokers and the at times strident groups within the American electorate, it is still very unclear as what the long-term position might be of the new Administration.

As well as the ongoing criticism to the TPPA and the election to the office of president of a declared opponent (irrespective of which candidate wins), there will be other pressing issues confronting the new President at home on the state of the economy, employment, security, and terrorism (to state just a few), and equally pressing issues abroad. Hence any TPPA ratification faces major hurdles in the short to medium term. It is quite possible that United States ratification will not occur before the end of the two-year ratification aspiration stated in Article 30.5.2, that is, by February 5, 2018 or just over 12 months after the inauguration of the new President. It is also quite possible that the eventual failure of the United States to ratify the TPPA at all will could also mean the failure of the "Asia-pivot" strategy.

\section{Ratification Environment amongst the Other Signatories}

In light of the troubled and contentious passage of the TPPA, even to the very conclusion of negotiations, and the ongoing domestic opposition and criticism of the Agreement that most of the remaining original signatories have faced, it is not surprising that they will need to subject the Agreement to close and detailed public consultation and assessment process. The necessity arises no doubt in part from constitutional considerations, but also legal and political reasons.

Singapore and Vietnam, both strong supporters of the TPPA, are reportedly

${ }^{26}$ United States The White House Office of the Press Secretary, "Statement by the President on the Trans-Pacific Partnership," https://www.whitehouse.gov/the-press-office/2015/10/05/statementpresident-trans-pacific-partnership, accessed 5 October 2015.

${ }^{27}$ Nora Kelly, “A High-Profile Push for President Obama's Pacific Trade Deal” The Atlantic, http://www. theatlantic.com/politics/archive/2016/08/obama-lee-tpp-singapore/494111/, accessed 2 August 2016; Lederman, "Brushing off Clinton's critique" 
moving towards an early ratification of the Agreement. The Vietnamese government is proposing to submit the TPP to the National Assembly for ratification at some time during the session commencing in July 2016. ${ }^{28}$ Singapore Prime Minister Lee Hsiong Loong has consistently advocated Singapore's support for the TPPA amongst the signatories, most recently during his State visit to the United States when he also strongly pressed the United States to endorse the Agreement, and warned of the dire consequences if this did not occur. Singapore was reportedly planning to introduce legislative amendments necessary to ratify the TPP into Parliament during 2016.

Brunei Darussalam is generally perceived as one of the major beneficiaries amongst the original signatories from the implementation of the TPPA, and the Sultan apparently has authority to commit his State.

Peru recently submitted the TPPA to the Congress for approval on July 21, and Prime Minister, Pedro Cateriano, has claimed that the deal is supposedly key to the development of the country. ${ }^{29}$ Newly elected president, Pedro Pablo Kuczynski, said he will sign the deal once it has been approved by the Congress, which could tentatively happen by the end of the year. While there has been some opposition to the Agreement, it has not been of the dimension of other signatories, and within Parliament should not prevent the legislation being passed.

Malaysia has already taken significant steps towards ratifying the TPPA, with the Parliament on January 28, 2016 approving a resolution to approve and ratify the Agreement - prior to the actual signing of the Agreement in New Zealand on February 5, 2016. According to International Trade and Industry Minister Mustapa Mohamed, Malaysia will most likely be able to complete its domestic ratification legal procedures for the TPPA by mid-2017, with the legislative requirements to comply with the TPPA commitments to be presented to Parliament by the first half of 2017.30

Should these four signatories each ratify the TPPA, which seems likely, they will constitute the balance of the six members and 85 percent of combined GDP necessary to bring the TPPA into force - assuming, of course, that the United States and Japan still ratify.

\section{INDONESIA AND THE TPPA}

On October 26, 2015, during his State visit to the United States, President Widodo announced that Indonesia would join the TPPA. ${ }^{31}$ He subsequently declared that this accession would occur within two years, much to the apparent consternation of both a number of commentators and government departments. ${ }^{32}$ The announcement reportedly took both the media and government departments by surprise, leading to warnings of dire consequences on the grounds that Indonesia could not be ready to join within the (aspirational) two-year time frame declared by the President.

${ }^{28}$ VietnamNet “Vietnamese National Assembly to approve TPP in July," http://english.vietnamnet.vn/ fms/government/152933/vietnamese-national-assembly-to-approve-tpp-in-july.html, 23 March 2016.

${ }^{29}$ Alternet, "Is the TPP Falling Apart?," http://www.alternet.org/economy/tpp-falling-apart, accessed 28 August 2016.

${ }^{30}$ New Straits Times, "Malaysia to complete domestic ratification process for TPPA by mid-2017," New Straits Times, http://www.nst.com.my/news/2016/05/146336/malaysia-complete-domesticratification-process-tppa-mid-2017-mustapa, 18 May 2016.

${ }^{31}$ Embassy of the Republic of Indonesia Washington D.C. the United States, "Widodo Announces Intent to Join Trans-Pacific Partnership Agreement (TPP)," Embassy of the Republic of Indonesia, Washington DC, United States, www.embassyofIndonesia.org/wordpress/wp-content/uploads/2015/10/2015.10.27News-Release, accessed 27 October 2015.

${ }^{32}$ Ibid. 
During his October visit President Widodo made his intentions and policy objectives driving the announcement very clear: "Indonesia is an open economy"... "Indonesia is open to investment." ${ }^{33}$ His comments display an imperative to open up Indonesian economy to much-needed greater international investment, and to enhance its competitiveness against other growing ASEAN economies. Membership of TPPA was held to be essential for Indonesian economic reform, growth and development. In an aside during the visit the then Indonesian Trade Minister, Thomas Lembong reinforced the imperative for Indonesia to develop and enhance its capacity to compete with other states in the region. He remarked that "Our greatest threat is Vietnam. We have fallen so far behind and I can tell that the President [Jokowi] is aware of this and very concerned..."34

The Joint Statement from The White House at the same time reinforced the economic priority of President Widodo when it stated that both parties:

"...recognized the importance of a predictable, open, and transparent economic policy framework, one that encourages foreign investment and promotes fair competition ... to facilitate greater two-way trade and investment and to promote private sector-led economic growth."35

The domestic media reaction to President Widodo's announcement not surprisingly has been vocal and mixed, ranging from predictions of bright futures through to warnings of doom and gloom. The Jakarta Post, for example, carried the following leaders at various times between the conclusion of the Agreement and its signing a few months later:

- “Trans-Pacific Partnership: Indonesia's lost opportunity?" (October 20, 2015);

- "Some say joining TPP suicidal for RI" (October 29, 2015);

- " “TPP officially signed, Indonesia to amend 12 laws" (February 5, 2016);

- "TPP may bankrupt Indonesia, activists say"( February 15, 2016);

- “Trans-Pacific Partnership: Should Indonesia join it or not?” (February 8, 2016);

- " "Indonesia needs more time to decide on joining TPP" (February 18, 2016).

In its campaign to join the TPPA, Indonesia will need to demonstrate to the TPPA members evidence of its commitment to a wide range of obligations and terms. Some will be defined by the Agreement itself, while others will be largely dictated by the TPPA members individually or collectively, depending on their own priorities, during the negotiation process. For example, the United States, having failed to secure a 12year period for data exclusivity associated with certain pharmaceutical biotic patents (instead having to settle for a 5-year period), may well seek concurrence for a 12-year period from Indonesia as one amongst many conditions for its approval of Indonesia's accession.

It is quite feasible that the accession negotiation process might progress without Indonesia having the opportunity to establish carve-outs or reservations to the same degree as were available to, and utilised by, the original TPPA signatories. The Agreement's provisions in respect of new accessions does not enshrine a right

\footnotetext{
33 Ibid.

${ }^{34}$ Ibid.

35 The White House, Office of the Press Secretary, "Joint Statement by the United States of America and the Republic of Indonesia," https://www.whitehouse.gov/the-press-office/2015/10/26/joint-statementunited-states-america-and-republic-indonesia, accessed 26 October 2016.
} 
to carve-outs or reservations to the applicants. On the contrary, the terms can be dictated on case by case basis by the members acting by consensus and acting on the advice of its own above-mentioned Commission.

Notwithstanding President's Widodo's original aspiration to join the TPPA within two years, the Agreement needs to come into force before Indonesia can even apply for membership and start the formal accession process. Assessment of its application will generate close scrutiny of its domestic compliance by all TPPA members who have themselves ratified the treaty in their respective jurisdictions. Application negotiations will be subject to trade and diplomatic wrangling, and eventual accession will then require consensus by all those TPPA members. Even assuming President Widodo meant his two-year timeline to commence after the Agreement comes into force, his objective will no doubt still be overly ambitious.

Some of those TPPA provisions and ensuing obligations arising therefrom have caused Indonesia grief and heartache in the recent past, such as investor state dispute settlement (ISDS) terms and provisions.

The declaration by former President Yudhoyono to cancel all 67 of Indonesia's bilateral investment treaties (BITs) with ISDS provisions, was largely driven by recent arbitration claims by Churchill Mining and Planet Mining against Indonesia over mining tenement rights disputes in East Kutai, Kalimantan. ${ }^{36}$ In a highly controversial ISDS-based case, UK-based mining company Churchill Mining and its junior Australian partner Planet Mining filed claims with the International Centre for Settlement of Investment Disputes (ICSID) against the Indonesian government for potentially almost $\$ 2$ billion in damages under the terms of Indonesian BITs with the United Kingdom and Australia respectively. ${ }^{37}$ Indonesia failed in its response to argue lack of jurisdiction by ICSID, thus enabling the dispute to proceed on the merits at some future date. President Yudhoyono's progressive cancellation strategy commenced, rather symbolically, with its Netherlands BIT when it expired in June 2015, but has since been continued by President Jokowi with the remaining BITs.

The TPPA Chapter 9 Investment, contains ISDS provisions generally similar to those in Indonesia's BITs (fairly universal), although certain moderating limits, exceptions and exclusions have been incorporated. Thus there is potential for increased scope for:

- excluding government actions on public health \& environmental grounds from ISDS-based claims in certain circumstances ${ }^{38}$;

- imposing exclusions or at least limitations on shelf companies being deemed to be investors and thus entitled to initiate ISDS claims ${ }^{39}$;

- $\quad$ imposing 3.5 year time limits claims ${ }^{40}$;

- increased transparency of proceedings ${ }^{41}$;

- $\quad$ awarding costs against frivolous claims. ${ }^{42}$

${ }^{36}$ See David Price, “Indonesia’s Bold Strategy on Bilateral Investment Treaties: Seeking an Equitable Climate for Investment?" Asian Journal of International Law 7, no. 1 (2017): 124-151. Doi: https://doi. org/10.1017/S2044251315000247.

37 Churchill Mining and Planet Mining v. Republic of Indonesia, ICSID Arbitral Tribunal Cases No. ARB/12/40 and 12/14, Decision on Jurisdiction (February 24, 2014).

38 TPPA, Art. 16. See also Chapter 29: Exceptions and General Provisions; Paragraph 5 Tobacco Control Measures.

${ }^{39}$ Ibid., Art. 9.15.

$40 \quad$ Ibid., Art. 9.21.

41 Ibid., Art. 9.24

${ }^{42}$ Ibid., Art. 9.23.4 and Art. 9.29 
Chapter 9 provisions would also require Indonesia to review its existing restrictions on foreign investment, and its "negative list" of sectors which are closed to foreign investment, subject to foreign ownership limits or where other special conditions apply. Again, the "negative list" received scrutiny during the Churchill Mining/Planet Mining cases, and Indonesia's claim that the Kalimantan mining tenements under dispute fell within the list's exceptions was not accepted by the tribunal. ${ }^{43}$

The TPPA's Chapter 9 also stipulates that the investment obligations apply "to measures adopted or maintained by: (a) the central, regional or local governments or authorities of that Party; and (b) any person, including a state enterprise or any other body, when it exercises any governmental authority delegated to it by central, regional or local governments or authorities of that Party". Indonesia's practice in decentralising political power and regulatory authority has led to a proliferation of lawmaking bodies and the consequent of laws and regulations, many of which are extremely unclear or overlap in highly problematic ways.

Both Churchill Mining and Planet Mining cases involve complaints arising in relation to laws or measures adopted by local lawmakers and regional authorities. Not only is Indonesia at the risk of claims based on actions taken by these local lawmakers, it would also be obliged under the TPP to take steps to improve regulatory coherence. As President Yudhoyono stated in response to the Churchill Mining/Planet Mining's complaints against the actions of regional officials:

This is a lesson for us, the incident in a county and then was taken to arbitration ... The first defendant, Yes, the President. Imagine if the hundred counties doing things like that, especially when we're on the wrong side and lose, it's a remarkable implication. $^{44}$

The provisions of the TPP regarding State-owned enterprises (SOEs) will also create headaches for Indonesia, since they regulate fair competition and the manner in which each member regulates its government's treatment of its SOEs. Indonesia has over 100 SOEs dominating key sectors of its economy and enjoying a range of formal and informal legal and economic advantages not shared by the private sector. Unless Indonesia could negotiate exceptions, it would need to ensure, among other things, that its SOEs conduct commercial transactions on the basis of commercial considerations, that SOEs do not discriminate against the enterprises, goods, and services of other TPPA parties and that the regulation of both SOEs and private companies is done in an impartial manner. ${ }^{45}$ Former Trade Minister Lembong suggested that at least 12 laws and bills on SOEs needed to be revised before Indonesia joined the TPPA, since the Agreement required non-discrimination between treatment of SOEs and non-SOEs, irrespective of whether they were local or foreign. ${ }^{46}$ Amendment of these regulations alone would take at least two years.

In some respects a projected delay in the United States' ratification and therefore the TPPA coming into force well beyond the envisaged two-year time frame could work to Indonesia's advantage for a number of reasons, namely providing invaluable time to:

${ }^{43}$ ICSID, Churchill Mining and Planet Mining v. Republic of Indonesia, ICSID Arbitral Tribunal Cases No. ARB/12/40 and 12/14, Decision on Jurisdiction (February 24, 2014), p. 36.

${ }^{44}$ President Susilo Bambang Yudhoyono, "Introductory Plenary Meeting of the Cabinet," http://www. presidenri.go.id/index.php/fokus/2012/06/28/8068.html, accessed 28 June 2012.

45 Ibid.

46 As cited in Ayomi Amindoni \& Anton Hermansyah, "TPP officially signed, Indonesia to amend 12 laws," The Jakarta Post, http://www.thejakartapost.com/news/2016/02/05/tpp-officially-signedindonesia-amend-12-laws.html, accessed 5 February 2016. 
- establish a clear and agreed position on its aims and outcome objectives for its TPPA membership as a platform for the hard negotiations that will accompany its membership application, including its position on carve-outs and reservations;

- endeavour to reach some degree of domestic political consensus on a number of contentious issues central to the TPPA, such as ISDS, SOE's and corruption;

- identify and work on current domestic legislation and regulation that will require amendment, or new legislation and regulation that will need to be drafted and debated;

- enabling it to take advantage of hard work and hard negotiating by number of signatory members negotiators to moderate or oppose the U.S. position on a range of issues, including again investments, ISDS, treatment of SOEs, amongst other things; and

- endeavour to establish some precedent and support for its position on contentious elements of the TPPA through its active position in respect of other regional trade agreements currently under negotiation and which could possibly come into force before the TPPA - such as the RCEP and the Indonesia-Australia Comprehensive Economic Partnership Agreement (IA-CEPA).

\section{INDONESIA'S OTHER PENDING TRADE DEALS}

Indonesia is currently pursuing a number of other regional and bilateral trade deals in addition to the TPPA, including the RCEP, and the Indonesia-Australia Comprehensive Economic Partnership Agreement (IA-CEPA). While the IA-CEPA is not in the same league as the TPPA by a long stretch, it still joins together the two largest economies in the region. The RCEP, on the other hand, is of a similar dimension to the TPPA, covers similar ground and issues. Of greater significance is the fact that, in many respects, it stands in direct competition to the TPPA. China, as the major promoter of the RCEP is not part of the TPPA negotiating membership, while the RCEP negotiating group does not include the United States.

\section{A. The Regional Comprehensive Economic Partnership (RCEP)}

However, the RCEP negotiating group includes Indonesia, as well as a number of other members who are also TPPA original signatories. ${ }^{47}$ President Joko Widodo in his State of the Nation Address on Indonesia's 71st Independence Day has declared that the Indonesian government will expedite the exploration of international trade deals and examine Indonesia's participation in international economic partnerships, referring equally to both the TPPA and the RCEP. ${ }^{48}$ Foreign Minister Retno Marsudi subsequently added that Indonesia was currently undertaking a cost analysis of the advantages and disadvantages of joining the TPPA, perhaps implying that Indonesian membership on any dictated terms should not necessarily be taken for granted. ${ }^{49}$

The RCEP is an ASEAN-centred proposal for a regional free trade area, which includes the ten ASEAN member states and those countries with existing FTAs with

47 The RCEP negotiating group includes China, South Korea, Japan, India, Australia, New Zealand and the ten ASEAN members Brunei Darussalam, Cambodia, Indonesia, Laos, Malaysia, Myanmar, Philippines, Singapore, Thailand and Vietnam.

48 Antara News "Indonesia accelerates exploitation of cooperative international partnerships," http://m.antaranews.com/berita/579160/indonesia-percepat-penjajakan-kerja-sama--kemitraaninternasional?utm source=twitterfeed\&utm medium=twitter , accessed 17 August 2016.

${ }^{49}$ Ibid. 
ASEAN, namely, Australia, China, India, Japan, Republic of Korea and New Zealand. The 16 RCEP participating countries account for almost half of the world's population, almost 30 per cent of global GDP, making it only marginally smaller than the TPPA. RCEP members are striving to finalise their treaty by the end of 2016 - many months before the United States is likely to ratify the TPPA and the Agreement can come into force. This would be a remarkable achievement in terms of international trade agreement creation, since the negotiations were only launched on the side of the East Asia Summit in Phnom Penh, Cambodia in November 2012.

The RCEP and the TPPA cover common ground in terms of being major comprehensive trade treaties both covering trade in goods, investment, intellectual property and regional cooperation, as well as their negotiating participants. The RCEP appears to set lower regulatory standards and less mandatory harmonisation amongst members than the TPPA; it also appears to make greater allowances for developing economies amongst its participating countries to reduce trade barriers at different rates. It also attempts to seek greater harmonisation of agreements already in place amongst its participating members.

From Indonesia's perspective, the outcomes achieved from a completed RCEP, comprising growing Asian economies, could conceivably provide Indonesia with benchmarks and negotiating strengths in those trade areas common to both the TPPA and the RCEP when it comes to negotiating on TPPA membership.

\section{B. The Indonesia-Australia Comprehensive Economic Partnership Agreement (IA-CEPA)}

Indonesia and Australia have recently re-started negotiations on the IndonesiaAustralia Comprehensive Economic Partnership Agreement (IA-CEPA). Negotiations originally commenced in September 2012, but stalled with little progress having been made.

While a bilateral trade agreement between the two regional neighbours whose trade relationship is currently well under-developed ${ }^{50}$ may appear to pale into insignificance in comparison with the dimensions of the TPPA and the RCEP, it nevertheless provides an opportunity for Indonesia to establish some precedents and to find an ally on some issues with which it will be confronted on its TPPA accession campaign. For example, Australia took the leading opposing view against the United States in respect of data exclusivity terms for pharmaceutical patents involving biotics, advocating for the 5-year term eventually agreed upon instead of the 12-year term sought by the United States. It also took a leading role in negotiating certain restraints on investments and ISDS, including insisted on carve-pits in respect of certain exclusions from ISDS application for government initiatives in public health (and specifically tobacco products).

Both the Indonesian and Australian governments have expressed a desire to conclude a mutually agreed treaty quickly. At the time of resumption of negotiations Australian Trade Minister Stephen Ciobo stated that "From Australia's perspective we want to ensure there are some early outcomes ... with a view to securing the comprehensive partnership agreement somewhere between the next 12 to 18 months"51, that is, before the end of 2017. In their joint ministerial statement on the launch of renewed negotiations the trade ministers of both countries declared that the final agreement should build upon the existing multilateral and regional agreements

\footnotetext{
${ }^{50}$ Indonesia ranks just 12 th amongst Australia's trading partners.

51 Anna Vidot, “Trade Minister Steven Ciobo mounts full-throated defence of TPP," http://abc.net. news/news/2016-08-10/ciobo-mounts-defence-of-tpp-stocktake, accessed August 2016.
} 
as well as negotiations between Indonesia and Australia. ${ }^{52}$

With a high level of ambition for an early successful conclusion on both sides, it is quite feasible that agreement could be concluded before the TPPA comes into force and Indonesia's formal application process is initiated. More importantly, as with the RCEP, the conditions agreed therein could conceivably provide Indonesia with precedents to assist it in establishing stronger positions in respect of its negotiation objectives and/or carve outs or exceptions.

\section{WIDER IMPLICATIONS OF THE TPPA}

It would be a mistake to view the TPPA as just a trade agreement, even if it is a mega agreement in terms of membership, trade volumes and combined GDP. It forms a key component of President Obama's "Asia-pivot," a rebalancing of American foreign policy to place greater emphasis and attention on the Asia-Pacific region that he initiated soon after he took office in 2008. To benefit from this shift in global geopolitical dynamism and sustainably grow its economy, the United States is building extensive diplomatic, economic, development, people-to-people and security ties with the region. ${ }^{53}$ The Asia pivot and hence the TPPA outcomes are seen as the external impetus the US with its struggling economy, increasing unemployment, and burgeoning deficit needs to bring it out of its economic woes. And Europe, still suffering under the Euro-crisis with a number of members already on the verge of national bankruptcy, is not in a position to provide that catalyst. Instead, the Asia-Pacific region is seen as the driver of global economic growth, and the United States seeks to be behind the steering wheel. The TPPA is perceived by some US commentators as one means to provide that impetus, by stimulating exports internationally and providing domestic jobs.

The TPPA demonstrates a quantum leap by the United States to place less reliance on Eurocentrism and trade and global financial relations previously based predominantly on relations with its major European trading partners. The US is increasingly recognising that it must position itself to establish stronger and controlling influences in respect of its trading relationships with Asian and Pacific rim countries. But it also recognises the increasing significance in world trade terms of the Asian economies, and in particular China \& India.

Ironically, if one of the attractions of the TPPA in terms of being able to eventually/ soon reach an agreement with high standards of sector protection is the absence of China and India, it is also one of the Agreement's biggest potential pitfalls. China and India together are now at the very centre of an Asian economic powerhouse that is itself at the heart of the global manufacturing industry. If the TPPA appears to be an attempt to take sides against China, it is likely to be highly divisive in a region where China is becoming more dominant, politically as well as economically.

\section{CONCLUSION}

Failure by the United States to ratify the TPPPA would create a power vacuum of sorts as well as the opportunity for China to assume a mantle as the dominant

\footnotetext{
${ }^{52}$ Australian Government Department of Foreign Affairs and Trade, "Joint statement by the Minister of Trade of the Republic of Indonesia and the Minister of Trade and Investment of Australia on the reactivation of negotiations on an Indonesia-Australia Comprehensive Economic Partnership Agreement," http://dfat. gov.au/geo/indonesia/Pages/joint-statement-on-ie-cepa-16-march-2016.aspx, accessed 16 March 2016.

53 Kurt Campbell and Brian Andrews, "Explaining the US 'Pivot' to Asia," Chatham House, The Asia Group, August 2013, p. 2.
} 
trading power in the Asia Pacific region. ${ }^{54}$ It enables China to continue to promote the RCEP and be its major driving force, shaping it to better suit its trade and economic expansion goals. In that sense, China's ambitions for the RCEP are akin to those of the Unites States' for the TPPA. It has been suggested by some that one difference of significance is that, whereas the United States appears motivated because of its declining power, China's motivation clearly stems from its rising power. ${ }^{55}$ The RCEP seems designed to help anoint China as the regional leader of Asia at the expense of the United States.

If the United States through its new President and its Congress stand by their presidential campaign rhetoric and determine to "rip up the Agreement (to use Republican candidate Donald Trump's words), it will not only miss an opportunity to consolidate its position in Asia-Pacific, it will also enable China to emerge as the major and largely uncontested trade power broker. And to re-enter that arena at a later stage and regain lost ground my well prove insurmountable.

Singapore Prime Minister Lee Hsien Loong, a strong supporter of the United States and its presence in Asia, recently placed the implications of a TPPA non-ratification decision by the United States into the broader geopolitical context. During a State visit to the United States in August 2016 Prime Minister Lee issued a dire warning to the United States against rejecting the TPPA. The Prime Minister stated that the United States' reputation is "on the line" when it comes to the TPPA. ${ }^{56}$ If the United States doesn't follow through on the Agreement, nations might not feel they can depend on the country with other matters.

"Your partners, your friends who have come to the table, who have negotiated, each one of them has overcome some domestic political objection, some sensitivity, some political cost to come to the table and make this deal .... And if at the end, waiting at the altar, the bride doesn't arrive, I think there are people who are going to be very hurt." ${ }^{\prime 57}$

Prime Minister Lee has warned that not only was the economic impact of the trade agreement at stake, but also America's leadership status in the world. ${ }^{58}$

The unpalatable dilemma now and in the immediate future for the United States, its new President and Congress, then, is how to perform a balancing act of opposing forces, namely the vocal domestic criticism and opposition to the TPPA with the harsh realities of international geopolitics and the imperative to establish and develop its hegemonic position in the Asia-Pacific. One uncertainty in all this is the extent to which the presidential candidates are being the pawns and victims of the domestic opposition or whether they have also been propellants fuelling the flames for their own domestic gain and thus risk being hoisted on their own petards.

As warned by Singapore, the United States can hardly afford the geopolitical and economic price that it would eventually have to pay if it declined to ratify the TPPA. Instead, it may need to carefully and diplomatically craft refinements by way of side negotiations and incremental changes that remain palatable to the other TPPA members. A heavy-handed exercise of trumping and out-trumping is most unlikely

54 Nicholas Smith, "China will be the winner if US backs out of the TPP," The Conversation, August 2, 2016, (online) at http://theconversation.com/china-will-be-the-winner-if-us-backs-out-of-the-tpp63328?utm medium=email\&utm.

55 Ibid.

56 Ibid.

57 See The Wall Street Journal "Obama, Singapore Prime Minister Lee Hsien Loong Vow to Push for Trade Pact," The Wall Street Journal, August 2, 2016, at http://www.wsj.com/articles/obama-to-hostsingapore-prime-minister-lee-hsien-loong-for-state-visit-1470144045

58 Ibid. 
to lead to the desired success. And by the time the TPPA is ready to come into force, the American electorate may well have moved on from the hue and cry and circus of the Presidential campaign of 2015-16. As one commentator recently opined rather succinctly, at present "the United States is having an anti-trade moment."59

In some respects this creates a window of opportunity for Indonesia in its campaign to join the TPPA. Its status and potential in terms of economic growth, consumer demand sectors, and industrial and commercial development makes it an important selection in any Asian grouping. Had not President Jokowi not already announced Indonesia's intention to join the TPPA, it would soon have been courted to join. The arguments raging for and against ratification in the United States provides Indonesia with the time it needs to examine and settle on its trade priorities and objectives to better suit its national imperatives and to establish its negotiating strategies. It also gives the President time to address the political resistance within his own party and Parliament, as well as the resistance from domestic producers, state-owned enterprises and other vested interests who feel threatened by the regulatory changes that would accompany the TPPA. It also provides time for Indonesia to strengthen and/or develop its own friendships and strategic alliances within the region and amongst other TPPA members to assist it in furthering its cause.

\section{POSTSCRIPT}

The US Presidential elections on 1 November 2016 and the subsequent US Electoral College vote resulted in a stunning and somewhat surprising result - electing Donald Trump to the Presidency.

As he had declared throughout his campaign, President-elect Trump quickly confirmed that one of his first actions after inauguration would be to withdraw from the TPPA. On January 23, 2017, the first working day after his inauguration, President Trump issued his first Executive Order to give formal effect to the withdrawal. The USTR formally advised other TPPA signatories and New Zealand as the TPPA depository on January 30:

".. the United States does not intend to become a party to the Trans-Pacific Partnership Agreement. Accordingly the United States has no legal obligations arising from its signature on February 4, 2016. The United States requests that New Zealand inform the other signatories.

The Unites States remains committed to measures designed to promote more efficient markets and higher levels of economic growth, both in our country and around the world. We look forward to further discussions as to how to achieve these goals." ${ }^{\prime \prime}$

The US action means that the TPPA in its present form cannot come into force since the 85 percent of combined GDP requirements of Article 35 cannot be met. However, this is not to say that the remaining 11 original signatories could not again convene and agree to amend or even delete this requirement in Article 35 in order to achieve a more realistic pragmatic outcome. In that sense, the TPPA is not necessarily entirely dead and buried, as President Trump declared during his campaign would happen. At the same time, the 11 signatories could also amend or delete some of the

$59 \quad$ Nora Kelly, “A High-Profile Push for President Obama's Pacific Trade Deal,” http://www. theatlantic.com/politics/archive/2016/08/obama-lee-tpp-singapore/494111/, 2 August 2016.

60 USTR, Letter to Trans Pacific Partnership Depository, New Zealand, January 30, 2017, at https:// ustr.gov/sites/default/files/files/Press/Releases/1-30-17\%20USTR\%20Letter\%20to\%20TPP\%20 Depositary.pdf 
more contentious provisions that were viewed as being driven by the United States and being overly corporate-biased, such as those relating to investor-state dispute settlement (ISDS), increased intellectual property protection and special rights for pharmaceuticals and medicines. They could also agree to initiate negotiations on possible membership of an amended TPPA with other countries outside the original signatories, such as Indonesia.

A number of the other signatories have signalled their intention, or shown by their actions, that they intend to proceed with domestic ratification of the TPPA. In a timing that was strategic rather than coincidental, Japan ratified the Agreement on Friday, just hours before Presidential inauguration. However, Prime Minister Abe has also said it would be "meaningless" to pursue bringing the TPPA into force without U.S. participation.

On a recent visit to New Zealand, the Australian Prime Minister announced that both countries were working together to salvage the TPPA. ${ }^{61}$ The New Zealand Prime minister added that while Australia and New Zealand did not have exactly the same trade interests, they were both keen to see the deal continue, even without the United States. Australia, among other nations, is looking for ways to salvage the TPP without the US.

The Australian Trade Minister Steve Ciobo was reported as stating at the world Economic forum in Davos, Switzerland in January 2017, that:

"I've had conversations with Canada, with Mexico, with Japan, with New Zealand, with Singapore, Malaysia ... I know that there's been conversations that have been had with Chile and with Peru. So there's quite a number of countries that have an interest in looking to see if we can make a TPP 12 minus one work ... Certainly I know that Indonesia has expressed a possible interest [in joining the TPPA] and there would be scope for China if we were able to reformulate it to be a TPP 12 minus one for countries like Indonesia or China or indeed other countries to consider joining and tto join in order to get the benefits that flow as a consequence". 62

Following the President's Executive Order, a spokesman of Singapore's Ministry of Trade and Industry stated that Singapore will be turning its attention towards other regional trade initiatives, and now looks to "study the new balance of benefits" with other TPP members in this new landscape. ${ }^{63}$

Peru is reportedly working with China and other Asian and Pacific Rim countries to incorporate elements of the Trans-Pacific Partnership into a new agreement following the United States' withdrawal, ${ }^{64}$

President Trump has expressed his intention to pursue bilateral trade agreements with both TPPA signatories and other countries as an alternative to the TPPA. As recently as February 17, 2017, he reportedly pressed Prime Minister Abe, during the latter's state visit to the United States, to agree to a joint announcement on a future bilateral free trade agreement between the two countries, which pressure the Prime Minister partially resisted.$^{65}$ It is the first time a specific demand by the Trump

${ }^{61}$ Radio Times, "NZ and Australia to work together to salvage TPP - English," Radio Times, http:// www.bilaterals.org/?nz-and-australia-to-work-together, accessed 17 February 2017.

${ }_{62}$ BBC World. "Australia and New Zealand to pursue 'TPP 12 minus one', http://www.bilaterals. org/?australia-and-new-zealand-to, accessed 24 January 2017.

63 Business Times, "Singapore says TPP cannot come into effect, turns to other regional trade initiatives," http://www.businesstimes.com.sg/government-economy/singapore-says-tpp-cannot-comeinto-effect-turns-to-other-regional-trade, accessed 24 January 2017.

${ }^{64}$ Reuters Asia, "Peru to work with China, others on TPP alternative: president," Reuters Asia, January 24, 2017, at http://www.reuters.com/article/us-peru-trade-idUSKBN15829U, accessed 24 January 2017.

65 Japan Times, “U.S. urged Japan to refer to bilateral FTA in joint statement: sources,” http://www. 
administration surfaced regarding a bilateral trade pact since the United States withdrew from the TPPA. ${ }^{66}$

The United States and Indonesia had previously committed to Indonesia joining the TPPA. However, this former commitment could well be replaced with a move towards a bilateral trade agreement between the two countries. With Indonesia being a key and developing economy in the East Asian region, the move is a logical one, but it does pose a dilemma of sorts for Indonesia. A bilateral trade agreement will bring tougher demands from the United States, compared with multilateral agreements in which negotiations go hand in hand with compromise. President Trump has heralded numerous times his intention of negotiating agreements that are "fair to America," which could well mean that the current U.S. trade deficit with Indonesia of around \$9billion ${ }^{67}$ could be viewed as "unfair," and therefore a situation requiring adjustment (in the United States' favour).

But there would also be the option for Indonesia to enter into negotiations and even join, if a new and different TPPA emerged from the demise of the current TPPA.

As discussed earlier, the imperative for Indonesia to examine and settle on its trade priorities and objectives to better suit its national imperatives and to establish its negotiating strategies, and to strengthen and/or develop its own friendships and strategic alliances within the region and amongst other TPPA members becomes even stronger. Negotiations with the United States on a trade agreement outside the TPPA framework will be much tougher than the one that might have been negotiated within the framework.

japantimes.co.jp/news/2017/02/15/business/u-s-urged-japan-refer-bilateral-fta-abe-trump-jointstatement-sources/, accessed 16 February 2017.

${ }^{66}$ Ibid.

${ }^{67}$ See United States Trade Representatives, “U.S.-Indonesia Bilateral Trade and Investment,” at https:// ustr.gov/countries-regions/southeast-asia-pacific/Indonesia 


\section{Bibliography}

\section{Legal Documents}

International Centre for Settlement of Investment Disputes. Churchill Mining and Planet Mining v. Republic of Indonesia. ICSID Cases No. ARB/12//40 and 12/14. Decision on Jurisdiction. 24 February 2014.

Trans Pacific Partnership Agreement. Auckland, 4 February 2016.

\section{Articles}

Price, D. "Indonesia's Bold Strategy on Bilateral Investment Treaties: Seeking an Equitable Climate for Investment?" Asian Journal of International Law 7, no. 1 (2017): 124-151. doi: https://doi.org/10.1017/ $\underline{\mathrm{S} 2044251315000247}$

Campbell, Kurt and Brian Andrews. "Explaining the US 'Pivot' to Asia." Programme Paper, Chatham House, 1 August 2013.

\section{Websites}

Alternet. "Is the TPP Falling Apart?" http://www.alternet.org/economy/tpp-fallingapart. Accessed 28 August 2016.

Amindoni, A. and Hermansyah, A. "TPP officially signed, Indonesia to amend 12 laws." The Jakarta Post, February 5, 2016, at http://www.thejakartapost.com/ news/2016/02/05/tpp-officially-signed-indonesia-amend-12-laws. html, accessed 5 February 2016.

Antaranews. "Indonesia percepat penjajakan kerja sama kemitraan internasional [Indonesia accelerates exploitation of cooperative international partnerships]." http://m.antaranews.com/berita/579160/indonesiapercepat-penjajakan-kerja-sama--kemitraan-internasional?utm source=twitterfeed\&utm medium=twitter. Accessed 17 August 2016.

Australian Government Department of Foreign Affairs and Trade. "Joint statement by the Minister of Trade of the Republic of Indonesia and the Minister of Trade and Investment of Australia on the reactivation of negotiations on an Indonesia-Australia Comprehensive Economic Partnership Agreement," March 16, 2016, at http://dfat.gov.au/geo/indonesia/ Pages/joint-statement-on-ie-cepa-16-march-2016.aspx

---. “Joint Statement from Trans-Pacific Partnership Ministers' Meeting in Arequipa, Peru." http://dfat.gov.au/trade/agreements/tpp/news/Pages/news. aspx. Accessed 23 May 2016.

---. "TPP text and associated documents." http://dfat.gov.au/trade/agreements/ tpp/official-documents/Pages/official-documents.aspx. Accessed 6 October 2016.

---. “Trans-Pacific Partnership Ministers' Statement." http://dfat.gov.au/trade/ agreements/tpp/news/Pages/trans-pacific-partnership-ministersstatement.aspx. Accessed 4 February 2016.

---. “Trans-Pacific Partnership Agreement: Latest News.” http://dfat.gov.au/trade/ agreements/tpp/pages/trans-pacific-partnership-agreement-tpp.aspx. 
Accessed 17 May 2016.

BBC World. "Australia and New Zealand to pursue 'TPP 12 minus one'” http://www. bilaterals.org/?australia-and-new-zealand-to. Accessed 24 January 2017.

Beshudi, A. "Obama puts Congress on notice: TPP is coming." http://www.bilaterals. org/?obama-puts-congress-on-notice-tpp. Accessed 12 August 2016.

Business Times. "Singapore says TPP cannot come into effect, turns to other regional trade initiatives." http://www.businesstimes.com.sg/governmenteconomy/singapore-says-tpp-cannot-come-into-effect-turns-to-otherregional-trade. Accessed 24 January 2017.

Cane, P. and D. Nakamura. "McConnell warns that trade deal can't pass Congress before 2016 elections." https://www.washingtonpost.com/politics/ mcconnell-warns-that-trade-deal-cant-pass-congress-before-2016elections/. Accessed 14 December 2015.

Freshfields Bruckhaus Deringer. "Trans-Pacific Partnership." http://www.freshfields. com/Current status tpp/. Accessed 24 January 2017.

http://en.tempo.co/read/news/2016/08/17/056796604/Indonesia-to-ExplorePossibility-of-Joining-TPP. Accessed 17 August 2016.

Japan Times. "U.S. urged Japan to refer to bilateral FTA in joint statement: sources." http://www.japantimes.co.jp/news/2017/02/15/business/u-s-urgedjapan-refer-bilateral-fta-abe-trump-joint-statement-sources/. Accessed 16 August 2017.

Kelly, N. "A High-Profile Push for President Obama's Pacific Trade Deal.” http:// www.theatlantic.com/politics/archive/2016/08/obama-lee-tppsingapore/494111/. Accessed 2 August 2016.

Lederman, J. “Brushing off Clinton's critique, Obama presses ahead on TPP.” http:// www.thejakartapost.com/news/2016/08/03/brushing-off-clintonscritique-obama-presses-ahead-on-tpp.html. 15 August 2016.

Lima, C. "Trump calls trade deal 'a rape of our country." http://www.politico. com/story/2016/06/donald-trump-trans-pacific-partnership224916\#ixzz4IotfOffD. Accessed 28 August 2016.

Needham, V. "Finance chair: Trade deal may need to be renegotiated." http://thehill. com/policy/finance/259426-hatch-concerned-tpp-may-fall-short-ofcongressional-expectations. Accessed 6 November 2016.

New Strait Times. "Malaysia to complete domestic ratification process for TPPA by mid-2017." http://www.nst.com.my/news/2016/05/146336/ malaysia-complete-domestic-ratification-process-tppa-mid-2017mustapa. Accessed 18 May 2016.

PBS Newshour. "Hillary Clinton says she does not support Trans-Pacific Partnership." http://www.pbs.org/newshour/rundown/hillary-clinton-says-shedoes-not-support-trans-pacific-partnership/. Accessed 7 October 2015.

President's Office of the Republic of Indonesia. "Introductory Plenary Meeting of the Cabinet." http://www.presidenri.go.id/index.php/ fokus/2012/06/28/8068.html. Accessed 28 June 2012.

Radio Times. "NZ and Australia to work together to salvage TPP - English." http:// www.bilaterals.org/?nz-and-australia-to-work-together. Accessed 17 
February 2017.

Reuters Asia. "Peru to work with China, others on TPP alternative: President." http:// www.reuters.com/article/us-peru-trade-idUSKBN15829U. Accessed 24 January 2017.

Smith, N. "China will be the winner if US backs out of the TPP." http://theconversation. com/china-will-be-the-winner-if-us-backs-out-of-the-tpp-63328?utm medium=email\&utm. Accessed 2 August 2016.

Tempo. "Indonesia to Explore Possibility of Joining TPP."

The Mainichi. “Gov't abandons plans for TPP ratification during current Diet session." http://mainichi.jp/english/articles/20160420/ $\mathrm{p} 2 \mathrm{a} / 00 \mathrm{~m} / 0 \mathrm{na} / 011000 \mathrm{c}$. Accessed 20 April 2016.

The Wallstreet Journal. "Obama, Singapore Prime Minister Lee Hsien Loong Vow to Push for Trade Pact." at http://www.wsj.com/articles/obama-to-hostsingapore-prime-minister-lee-hsien-loong-for-state-visit-1470144045. Accessed 2 August 2016.

Trump, Donald. "Republican presidential debate, Milwaukee." https://www.youtube. com/watch?v=kihtDxtcZ54. Accessed 10 November 2015.

United States Trade Representative. "Letter to Trans Pacific Partnership Depository, New Zealand." https://ustr.gov/sites/default/files/files/Press/ Releases/1-30-17\%20USTR\%20Letter\%20to\%20TPP\%20Depositary. pdf. Accessed 30 January 2017.

United States, The White House Office of the Press Secretary. "Joint Statement by the United States of America and the Republic of Indonesia." October 26, 2015, at https://www.whitehouse.gov/the-press-office/2015/10/26/ joint-statement-united-states-america-and-republic-indonesia. Accessed 26 October 2015.

---. "Statement by the President on the Trans-Pacific Partnership." https://www. whitehouse.gov/the-press-office/2015/10/05/statement-presidenttrans-pacific-partnership . Accessed 5 October 2015.

Vidot, A. “Trade Minister Steven Ciobo mounts full-throated defence of TPP." http:// abc.net.news/news/2016-08-10/ciobo-mounts-defence-of-tppstocktake. Accessed 10 August 2016. 